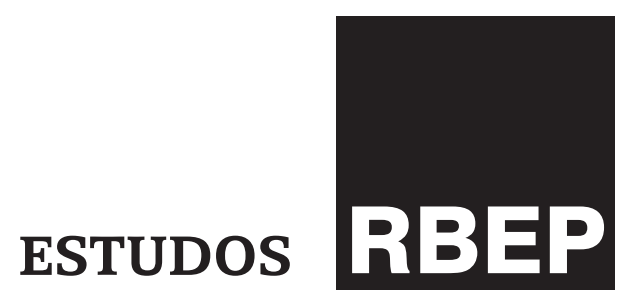

\title{
O conceito de coletividade de Anton Makarenko, em seu Poema pedagógico
}

Silvana Aparecida Bretas ${ }^{\mathrm{I}, \text { II }}$

Karla Gusmão Novaes ${ }^{\mathrm{III}, \text { IV }}$

http://dx.doi.org/10.1590/S2176-6681/360214427

\section{Resumo}

Trata-se de pesquisa bibliográfica que analisa o texto Poema pedagógico (1935), de Anton Makarenko, a fim de abordar o conceito de coletividade inscrito na experiência educacional da Colônia de Gorki, situada no longínquo e congelado território da então União das Repúblicas Socialistas Soviéticas (URSS). Makarenko, em seu texto narrativo, descreve vivências de suas práticas, após a Revolução Socialista, na colônia destinada à educação de jovens infratores. Para o educador, o coletivo se constrói na convivência diária entre educandos e educadores.

Palavras-chave: coletividade; educação socialista; processo de formação; experiência pedagógica; intelectual orgânico.

Universidade Federal de Sergipe (UFS), Aracaju, Sergipe, Brasil. E-mail: <s-bretas@ uol.com.br $>$; <http://orcid. org/0000-0003-1101-3272>.

II Doutora em Educação Escolar pela Universidade Estadual Paulista "Júlio de Mesquita Filho", Araraquara, São Paulo, Brasil.

III Escola Centro de Excelência Master, Aracaju, Sergipe Brasil. E-mail: $<$ karlanovaes4@gmail.com>; $<$ http://orcid.org/0000-00021690-6005>.

Iv Especialista em Gestão Escolar e Pedagogia Empresarial pelas Faculdades Integradas Pio X, Aracaju, Sergipe, Brasil. 


\section{Abstract \\ Anton Makarenko's concept of collectivity in his Pedagogical poem}

The article is a bibliographical research that analyzes the Pedagogical Poem (1935), by Anton Makarenko, in order to approach the concept of collectivity inscribed in the educational experience of Gorky Colony, located in the distant and frozen territory of the once Union of Soviet Socialist Republics (USSR). The Pedagogical Poem is a narrative that describes Makarenko's practices regarding the education of young offenders in the colony after the Socialist Revolution. For this educator, the collective is built around daily interaction between learners and educators.

Keywords: collectivity; socialist education; training process; pedagogical experience; organic intellectual.

\section{Introdução}

Este artigo procura compreender o conceito de coletividade em Poema pedagógico (1935), de Anton Makarenko, propondo analisá-lo como elemento fundamental de exposição de sua experiência pedagógica. A obra foi escrita após a Revolução Russa (1917), que provocou profundas mudanças sociais, como a eliminação da propriedade privada, a concepção de planejamento econômico centralizado Estado, o desaparecimento da escola privada, a destituição do poder religioso e a proposição da laicidade das instituições sociais, sobretudo da escola pública.

Anton Semionóvitch Makarenko viveu dois momentos históricos que foram imprescindíveis para sua prática pedagógica, o tzarismo e a Revolução Socialista Russa. Esses dois paralelos antagônicos contribuíram para a constituição do homem e do educador em que se transformara. Experiente em vida e em formação acadêmica nas lutas empreendidas pelos trabalhadores ucranianos, soube dialogar polemicamente com as teses de educadores modernos, como Rousseau (1712-1778), Froebel (1782-1852) e Montessori (1870-1952), que defendem ser a criança o centro do processo da formação. Makarenko deslocou esse centro para a coletividade de educandos, pois, para ele, a educação se realiza na e pela ação de todos, na medida em que o sentimento de pertencer e ser aceito na coletividade age como processo formador de conhecimento, moral e ética para o bem comum. Na perspectiva de sua pedagogia, é preciso deixar de considerar o aluno de modo abstrato, como ser ideal e objeto da educação que se manipula conforme objetivos previamente traçados, para olhá-lo a partir de suas condições reais de vida, devendo, portanto, a educação ser centrada na coletividade, como maneira de se superarem os frágeis laços sociais impingidos pela vida marginalizada. Mas de que forma Anton Makarenko 
pratica a pedagogia que tem a coletividade como centro da ação educativa e se torna, portanto, objeto da educação comunista?

Seu objetivo era educar os integrantes da Colônia Gorki conforme suas capacidades, qualidades e limites, para realizar tanto o trabalho manual quanto o intelectual e, assim, contemplar suas necessidades individuais e coletivas, à medida que incorporavam a ideologia socialista. Entre as várias obras do educador, optou-se por Poema pedagógico por entendermos que se trata de sua principal obra educacional, possuidora de inegável valor literário, uma vez que abre mão da escrita do gênero textual científico, para narrar a construção de um difícil processo educativo na Colônia Gorki (1920 a 1928). Nesse caso, a constituição da coletividade educacional representava a restituição da dignidade e da esperança a jovens jogados à própria sorte naquela depauperada e remota localidade da União das Repúblicas Socialistas Soviéticas (URSS).

O processo de ensino-aprendizagem não se estabeleceu sem contradições e paradoxos a respeito das ações educativas do ucraniano; ao contrário, no bojo de sua inequívoca vontade de fortalecer o coletivo, recorreu a práticas questionáveis para a formação humana. Nesse sentido, entende-se que, ao revisitar sua obra, não se propõe considerar a experiência educativa de Makarenko como natural, tampouco se esforçar para aperfeiçoá-la, eliminando seus aspectos negativos ou contraditórios. Apenas se propõe procurar observar no desenvolvimento dessas contradições, no emergir do dado negativo e até antagônico, a única via histórica de transformação (Manacorda, 2000).

Na perspectiva presente, a narrativa de Makarenko, mais do que o gênero de texto científico, possibilita a apreensão da vitalidade daquele processo, daquele local e, sobretudo, daqueles sujeitos. Por isso, este estudo se enquadra na modalidade de pesquisa bibliográfica, uma vez que foi elaborado a partir de obra previamente selecionada e com critérios de classificação dos temas para sua interpretação. Para Fachin (2006, p. 119), a pesquisa bibliográfica é "fonte inesgotável de informações, pois auxilia na atividade intelectual e contribui para o conhecimento cultural". Além disso, entende-se que é necessário discutir os procedimentos metodológicos de um trabalho acadêmico que tem por finalidade a leitura e a interpretação de uma obra. Por isso, após a leitura atenta e sistematizada, delimitou-se o tema e definiu-se Poema pedagógico (volume 1) como objeto deste estudo.

Na obra, encontraram-se subsídios suficientes para refletir sobre o conceito de coletividade examinado neste trabalho, sem que, no entanto, se desconhecessem os volumes 2 e 3. Na proposta metodológica, como apoio interpretativo recorreu-se à principal comentadora brasileira de Makarenko, Cecília Luedemann (2002), e ao também comentador René Capriles (1989). O contexto sócio-histórico da ex-URSS pré-Revolução, da Revolução de Fevereiro, da Revolução de Outubro de 1917, bem como os líderes revolucionários do Partido Bolchevique são elementos fundamentais para penetrar no sentido do conceito de coletividade tão caro para a obra pedagógica de Makarenko. 


\section{O contexto sócio-histórico do Poema pedagógico}

Para interpretar um autor tão vigoroso como Makarenko, apropriou-se do conceito de intelectual orgânico formulado por Gramsci (2000) e entendido como apropriado para definir a reflexão e ação desse jovem educador socialista.

Para Gramsci (2000) cada sociedade gera sua própria categoria de intelectual, resguardando, porém, suas especificidades conforme os arranjos sociais e históricos. Mas, antes de tudo, o marxista italiano defende que todos os homens são intelectuais, mas nem todos exercem essa função como especialista. Ou seja, cada homem, vivendo a cultura, pensa sobre ela e sobre ela age; há aqueles, entretanto, que exercem uma complexa função de dar homogeneidade e consciência ao grupo social que representam, no contexto do modo de produção desta ou daquela sociedade. Tal como explica Gramsci (2000, p. 15):

Todo grupo social, nascendo no terreno originário de uma função essencial no mundo da produção econômica, cria para si ao mesmo tempo, organicamente, uma ou mais camadas de intelectuais que lhe dão homogeneidade e consciência da própria função, não apenas no campo econômico, mas também no social e político.

Entende ele, também, que cada nova geração de intelectuais encontra categorias de intelectuais pré-existentes à sua e que, mesmo com as transformações mais radicais, procura manter a hegemonia e a consciência tradicional, de modo que põe em luta as diferentes perspectivas entre os grupos de intelectuais, conforme as transformações históricas ocorridas. Recorrendo novamente a Gramsci (2000, p. 16), ver-se-á que:

Todo grupo social "essencial", contudo, emergindo na história a partir da estrutura econômica anterior e como expressão do desenvolvimento desta estrutura, encontrou - pelo menos na história que se desenrolou até nossos dias - categorias intelectuais pré-existentes, as quais apareciam, aliás, como representantes de uma continuidade histórica que não foi interrompida nem mesmo pelas mais complicadas e radicais modificações das formas sociais e políticas.

Mediante o exposto, o papel dos intelectuais revela uma relação direta entre as camadas de intelectuais e a estrutura do mundo da produção, entretanto, essa relação não é imediata tal como as categorias de trabalhadores do chão da fábrica, mas sim mediatizada com toda a organização social, com o conjunto das superestruturas, do qual todos "os intelectuais são precisamente os 'funcionários'" (Gramsci, 2000, p. 20). Ainda aqui, a atividade do intelectual deve ser diferenciada conforme o envolvimento político com o grupo social ao qual pertence. Assim, Gramsci (2000, p. 23) distingue basicamente duas categorias de intelectuais:

O ponto central da questão continua a ser a distinção entre intelectuais como categoria orgânica de cada grupo social fundamental e intelectuais da categoria tradicional, distinção da qual decorre toda uma série de problemas e de possíveis pesquisas históricas. 
O intelectual orgânico é portador das pretensões políticas da classe social de onde se origina, ele defende e traduz através de seu discurso e ação a concepção de mundo que está nascendo. O intelectual orgânico da classe trabalhadora tem por objetivo que o povo excluído agora se torne os "novos intelectuais".

Nascido em $1^{\circ}$ de março de 1888, em Bilopólie, província de Kharkov, na Ucrânia, filho de Semion Grigorievich - operário ferroviário - e de Tatiana Mikhailovna - dona de casa, Makarenko foi uma criança frágil devido ao rigoroso inverno ucraniano e, por isso, sua rotina infantil era ouvir as histórias contadas por sua mãe, o que o incentivou a aprender a ler e escrever antes mesmo de chegar à escola, fazendo surgir nele o amor pela literatura. Em 1895, ingressou na escola primária, onde se tornou o melhor aluno da turma.

Em agosto de 1904, aos 16 anos, ingressou em curso de preparação para o magistério primário. Em setembro de 1905, foi empregado como professor de língua russa na Escola Primária Ferroviária de Kharkov. Nessa escola, houve um incidente com um dos alunos participantes da avaliação de aprendizagem, que consistia em medir os avanços que os discentes haviam auferido e divulgar os resultados por ordem de classificação. Um dos alunos, que ficara em $37^{\circ}$ lugar, tinha tuberculose e entrou em depressão profunda em consequência do resultado obtido. O educador se sentiu tão amargurado que foi até a casa do menino, pediu perdão, decidiu repensar sua metodologia e concluiu que a educação não é um ato isolado da realidade, estando vitalmente relacionada a ela.

Influenciado pelas ideias humanistas de Gorki, nasceu um intelectual preocupado em humanizar a relação com seus alunos, cujo foco era fazêlos pessoas felizes. Assim, repensou seus métodos e percebeu que era importante levar em consideração a individualidade, mesmo quando se educa o coletivo. Makarenko não se esquivou da vida política e passou a participar, com outros professores, da organização do jornal Novaia jizn, que já refletia as ideias, em ascensão na Ucrânia, sobre mudanças na educação e na sociedade, que não suportava mais os abusos do Tzar (Luedemann, 2002, p. 72).

Desde cedo, teve consciência dos pequenos passos dados pela Revolução até a efetiva instalação da URSS e, por isso, sugeriu mudanças na estrutura pedagógica da escola ferroviária, cujos objetivos se limitavam a conhecimentos utilitários, visando à produção de mão de obra escravizada. Suas ideias não foram aceitas, gerando muitas discussões com o diretor, o que o levou a ser transferido para outra escola, situada na estação ferroviária de Dolinskaia, na qual foi empossado inspetor de instrução pública (Capriles, 1989). Luedemann (2002) menciona que o educador, visado pela burocracia tzarista, foi transferido para uma escola afastada, na estação ferroviária de Dolinskaia, consistindo sua punição em ser desligado da sala de aula e trabalhar como inspetor de ensino da escola. 
O educador, de alguma forma, implementara práticas que davam condições para os educandos compreenderem que o socialismo não era somente um modelo econômico, mas todo um processo de transformação da sociedade. Ao chegar à escola em Dolinskaia (1911), o jovem Makarenko sentiu-se confiante, porquanto se via como diretor que agora teria certa autoridade para fazer mudanças educacionais. A partir de então, passou a organizar atividades com as famílias a fim de aproximá-las da instituição, realizando seu sonho de envolver a comunidade na escola. O projeto cultural abrangia artes plásticas, teatro e música, com o objetivo de preparar os educandos e pais para a luta pela liberdade. Organizou também reuniões políticas clandestinas, aos domingos, com professores e operários.

Em 1914, iniciou curso superior no Instituto Pedagógico de Poltava, estabelecimento que formava professores para o ensino secundário, concluindo-o em 1917, com homenagens por se destacar nos estudos. Na sua formação, foi influenciado pelo escritor Máximo Gorki, que retratou com fidelidade a realidade do jovem proletariado e dos rebeldes camponeses expulsos de suas terras (Luedemann, 2002).

Apesar de ocupado com seus intensos estudos, Anton Makarenko encontrou a mulher com quem se casaria em 1927, Galina Stakhievna Salkó, importante dirigente do Comissariado do Povo para a Instrução Pública da Ucrânia. O romance teve início durante visita dela à Colônia Gorki. Familiarizada com a ambiência de instituições de reeducação, a visitante se impressionou com a forma intensamente respeitosa com que foi recebida. Makarenko, embora não quisesse se envolver com alguém, acreditou que ela era especial, pois se importava com os jovens que precisavam de intensos cuidados.

Na dinâmica histórica das transformações por que passava o antigo Império Russo (1721-1922), a população do país e das colônias dependentes, como a Ucrânia, subsistia em péssimas condições de vida, sustentando-se da agricultura, apesar de a maior parte das terras produtivas constituir propriedade da nobreza. Na cidade, a situação dos operários não era diferente. Eles trabalhavam em excesso nas poucas indústrias existentes na Rússia daquele período e recebiam salários muito baixos. A Igreja controlava a instrução popular, e os poucos camponeses e operários que a frequentavam recebiam instrução não científica, fundamentada em textos eclesiásticos. Segundo Capriles (1989), no início do século 20 a Rússia era uma das nações mais atrasadas do mundo no âmbito da educação, sendo a maioria da população analfabeta.

A Revolução de 1917 provocou mudanças nas escolas públicas russas, ao assumir um caráter democrático e o direito de ensinar a língua vernácula (ucraniana). A poesia, o teatro, o cinema, a arquitetura e as artes plásticas expandem o universo de possibilidades criativas (Capriles, 1989). Desde 1917, Krupskaya, esposa de Lenin, representava a política de orientações culturais dos bolcheviques e reivindicava as promessas da burguesia de derrubar o método educacional tzarista e implantar a igualdade de educação para todos. Em suas palavras, a educação socialista deveria 
[...] da la vida a los jovenes obreros. La vida les educa en el noble espiritu de la solidaridad proletaria de clase, hace que comprendan y amenla divisa: ‘Proletarios de todos los países, uníos! y los coloca en las filas de los luchadores ‘por un mundo fraternal y la sagrada libertad`. (Krupskaya, 1917).

Makarenko, já experiente na educação de crianças proletárias, atentava-se às orientações políticas leninistas, cuja tônica era a formação da República dos Sovietes (Conselhos Populares) e a nacionalização dos bancos e da propriedade privada (Lênin, 1990). Assim, participava dos debates sobre a revolução cultural e a construção da escola comunista, propostos pelo Comissariado da Instrução Pública.

Por outro lado, um dos principais organizadores dessa ação cultural e educativa, Anatoli Lunatcharski, criou a legislação educacional da União Soviética e instituiu como meta a alfabetização de todos e a politização dos trabalhadores. Para isso, diminuiu duas horas por turno da jornada de trabalho, tornando possível aos operários os estudos escolares (Lunatcharski, 1917).

De 1920 a 1928, Makarenko foi diretor da Colônia Gorki, que atendia crianças, adolescentes e jovens que viviam na marginalidade econômica e social. Essa experiência é intensa e extensamente relatada em Poema pedagógico. Escrita após a Revolução Russa, a obra mostra suas reflexões sobre a formação do homem para construção de um novo modelo social em que o coletivo prevalecesse sobre o individual. O primeiro dos três volumes foi escrito em 1933, mas só foi traduzido para o português em 1985, trabalho empreendido pela escritora Tatiana Belinky, cuja iniciativa nos ensejou conhecer Makarenko. Impressiona a forma literária com que relata suas experiências na Colônia. Trata-se do testemunho de seu mentor, que, por meio de diálogos, vivências e episódios, revela o paradigma educacional moderno, nascido dos embates entre os mundos capitalista e socialista.

Makarenko deixou a Colônia após ter sido processado sob a acusação de usar práticas pedagógicas erradas para a construção do cidadão soviético. Foi convidado, em 1929, pelos tchequistas ${ }^{1}$ a dirigir a Comuna Dzerjinski em Kharkov, com proposta de autogestão.

Depois de cinco anos de trabalho, Makarenko deixou a Comuna, mudou-se para Kiev com a esposa e o filho adotivo e dedicou-se a seus livros, concluindo Poema pedagógico, que havia iniciado, ainda na Comuna, em 1933. Em 1937, a Colônia foi fechada, sendo os alunos enviados para estudar ou para atuar no Departamento Nacional. O educador soviético manteve contato com os gorkianos e comuneiros, muitos dos quais se tornaram aviadores, diretores de internato e, sobretudo, cidadãos de verdade, em virtude da educação que lhes foi dispensada (Luedemann, 2002).

Makarenko viajou de trem, em $1^{\circ}$ de abril de 1939, para expor suas ideias do coletivo a alguns amigos, mas foi encontrado morto, vítima de ataque cardíaco. Era o fim de sua jornada, mas não de sua herança pedagógica, que, por meio de sua viva narrativa, ficará para sempre na memória dos educadores contemporâneos.
Tcheká: comissão extraordinária de toda Rússia para a luta contra a sabotagem e a contrarrevolução (Luedemann, 2002). 


\section{O conceito de coletivo no Poema pedagógico}

Poema pedagógico foi escrito na intenção de que as sociedades russa e internacional conhecessem como é possível transformar jovens exdelinquentes em novos homens. Luedemann (2002) relata que o educador às vezes escrevia tendo a companhia de Semion Karabanov, ex-colono. Essa presença foi certamente inspiradora, porque Semion era um dos vários colonistas que haviam tomado nova consciência de sua própria vida e das condições sociais, graças às efetivas intervenções das práticas de Makarenko.

A Colônia Gorki ocorreu em três localidades diferentes: na província de Poltava (1920-1923); em Trepke (1923-1926), propriedade rural abandonada; e na província de Kuriaj (1926-1928). Makarenko é convocado, em 1920, por Zavgubnarobraz, chefe do Departamento da Província, para assumir a direção da Colônia Gorki, na qual se realizaria a reeducação de jovens delinquentes soviéticos. Na conversa, ficou claro que a convocação era para tarefa difícil, visto que envolvia a concepção e criação de novo homem para a sociedade soviética. Assim se inicia o diálogo:

- Mesmo antes da Revolução já se sabia lidar com esses vagabundos. Já existiam as Colônias para delinquentes juvenis. [palavras de Makarenko]

- Isso não nos serve, sabe... O que foi antes da Revolução não presta para nós. [palavras de Zavgubnarobraz]

- Certo. Isso significa que temos que criar o homem novo de maneira nova.

- De maneira nova, isso mesmo, nisso você está certo.

- Mas ninguém sabe de que jeito fazer isso.

- Nem você sabe?

- Nem eu sei. (Makarenko, 1985, p. 12).

Nesse diálogo, o modo com que Makarenko se refere aos jovens revelando seu julgamento de que esses são vagabundos e delinquentes por escolha própria, como se se tratasse de um problema imanente à subjetividade - caracteriza o que se entende por preconceito. No entanto, a dúvida é o tom da conversa, deixando entrever a coragem requerida para assumir tal empreitada. Além disso, a crença social soviética apostava na inviabilidade de ressocialização, por meio da educação, dos considerados delinquentes, o que implicava, para quem se dispusesse fazer carreira na Colônia, arriscar a própria reputação. No antigo Império, todos os reformatórios tinham função de prisão, servindo apenas para a correção dos delinquentes. Diante da fome e do desespero, a criminalidade aumentou, fato que incomodava muito o governo soviético.

Por isso, Máximo Gorki, com o apoio de Lenin, formou a Comissão para a Luta Contra a Delinquência Infantil. Gorki tinha por meta solucionar, de algum modo, o caos instalado pela instabilidade política da transição do Império Tzarista para o Governo Provisório Russo. Assim, o primeiro passo foi transferir da justiça para a educação as questões pertinentes ao acolhimento e tratamento dos jovens oriundos da marginalidade criminosa. 
Posteriormente, optou-se por instituir colônias para acolher esses menores (Capriles, 1989).

A Colônia Gorki situou-se inicialmente em Poltava, Ucrânia, nas encostas de colinas arenosas que se estendiam até uma floresta. Nessa Colônia, num dos cantos do terreno, havia cinco estruturas de tijolos em forma de caixote. Quando da chegada de Makarenko à Colônia, por esta não gozar do respeito dos vizinhos, quase tudo fora roubado, inclusive o pomar. Segundo Makarenko (1985), somente o bufê - grande armário - restara naquele lugar, porque era demasiado grande para passar pela porta, o que fez com que não fosse subtraído do local.

Na Colônia, o educador encontrou o chefe de abastecimento, Kaliná Ivánovitch, que se tornou seu braço direito e chefe da economia da Colônia. Acrescida às deficiências estruturais, ele se deparou com a recusa de atuar dos educadores, pelos motivos mencionados anteriormente. O educador escreve: "Eu já estava quase me entregando ao desespero, na procura de colaboradores pedagógicos: ninguém estava disposto a se dedicar à tarefa de educar o novo homem na nossa floresta" (Makarenko, 1985, p. 19). Tempos depois, chegaram à Colônia duas educadoras: Iekaterína Grigórievna e Lídia Pietróvna, sendo a primeira um "lobo pedagógico" e a última "muito jovem" (Makarenko, 1985, p. 20).

Em 4 de dezembro de 1920, começaram realmente as atividades pedagógicas na Colônia. Os primeiros educandos foram seis rapazes: Zadórov, Burún, Vólokhov, Bendiuk, Gud, Tarantês, entre os quais quatro tinham 18 anos de idade e foram enviados à Colônia por assalto domiciliar à mão armada; os demais eram menores e haviam sido condenados por furto. Eles foram bem recebidos e alimentados, tendo Makarenko iniciado os trabalhos com discurso em que destacava a necessidade de os jovens deixarem o passado e seguirem em frente. Esse era o ponto forte do discurso, retomado em diferentes situações ao longo da trajetória da Colônia Gorki, uma vez que, para o educador bolchevique, era fundamental esquecer o que passara - a vida diária necessitava disso. Insistia o educador em afirmar que não importava quem tinham sido antes de chegar àquele ambiente, mas sim quem seriam dali para frente. No dia seguinte, Lídia relatava a Makarenko sua imensa dificuldade em conversar com eles:

- Eu não sei como falar com eles. Eu lhes digo: é preciso ir até o lago buscar água, e um deles, aquele - o do corte de cabelo - vai calçando as botas e diz, quase me enfiando a bota na cara: "está vendo, o sapateiro me fez umas botas muito apertadas"! (Makarenko, 1985, p. 21).

Os alunos ofendiam e ignoravam os professores, saíam da Colônia e só voltavam quando desejavam. Ainda assim, o educador disse que não havia perdido a esperança de inventar uma maneira de entender-se com os educandos. Makarenko relata que os primeiros meses foram desesperadores e que a sensação era de que todas as leituras e teorias não resolveriam os problemas. Na verdade, era imprescindível observar os fenômenos reais em 
busca de saídas importantes para o processo de educação dos colonistas. Assim, ao suposto descarte da teoria, refazia e reconstruía a unidade entre teoria e prática:

Quanto a mim, o resultado principal dessas leituras foi uma convicção firme, e, subitamente, não sei por que, fundamental, de que nas minhas mãos não existia nenhuma ciência nem teoria nenhuma, e que a teoria tinha de ser extraída da soma total dos fenômenos reais que se desenrolavam diante dos meus olhos. (Makarenko, 1985, p. 24).

Ao prescindir de qualquer teoria, entregava-se à experiência que se constituía a cada dia e pelo sujeito que, aleatoriamente, fora escolhido pelo destino para compor o que viria a ser o coletivo da Colônia de Gorki. Provavelmente, as teorias por ele assimiladas não eram aplicáveis de forma direta, mas, antes de tudo, essa situação significava a constituição teórica e prática a um só tempo, cujo fundamento era a crença de que o processo educativo deveria costurar a soma total dos fenômenos. Uma experimentação pedagógica própria à escola comunista estava se estabelecendo na Rússia pós-Revolução, pois, apesar de estarem postos os princípios gerais da educação socialista - o trabalho como princípio educativo, a escola unitária e a formação da coletividade operária -, a realidade cotidiana desafiava a práxis revolucionária de Makarenko, para quem a classe operária tinha a tarefa histórica de construir uma nova civilidade humana posto que suas condições materiais e ideológicas pressupunham a luta pela vida e pela transformação social.

Não obstante, o relacionamento dos educadores com os jovens ficava cada dia mais atritado, culminando em atos violentos por parte do educador ucraniano. Certo dia, Anton Makarenko pediu a Zadórov que fosse rachar lenha, ao que ouviu como resposta: "Vá rachar você mesmo" (Makarenko, 1985, p. 25). Diante dessa resposta, levantou o braço e aplicou um bofetão no rosto de Zadórov. Em seu relato, o educador afirma que se apavorou e, quando ia bater mais ainda, ouviu: "Desculpe, Anton Semiónovitch..." (Makarenko, 1985, p. 25). Depois disso, todos foram rachar lenha. Não é possível considerar que o fato seja um ato educativo. Independentemente do contexto histórico ou mesmo da eventual permissividade quanto à aplicação de violência física na escola do início do século 20 - que a admitia sem que a sociedade se escandalizasse -, destaca-se que a efetivação da ordem ocorreu por medo de novas repreendas.

Luedemann (2002, p. 126) afirma: "A partir daí os primeiros educandos entenderam que era melhor aprender a trabalhar e conviver no coletivo do que voltar para cumprir suas penas na prisão". No dia seguinte, as educadoras o interpelaram, tendo Lídia mantido com Makarenko o seguinte diálogo:

- Então o senhor já encontrou um método? Como no seminário, não é?

- Deixe-me em paz, Lidóchka!

- Não, o senhor me diga; vamos quebrar caras? Eu também posso? Ou só o senhor? 
- Lidóchka, eu lhe direi depois. Por ora nem mesmo eu sei. Espere um pouquinho.

- Muito bem, vou esperar. (Makarenko, 1985, p. 30).

Nesse dia, o educador avisou que teriam de manter a disciplina caso quisessem continuar ou então teriam de ir para onde julgassem melhor. Ademais, deveriam arrumar os quartos e estudar em conjunto, pois a escola era indispensável. O incidente havia mudado a postura de Makarenko, entretanto, ele alerta que não havia encontrado na violência a solução onipotente, mas sim verificara que o fato constituía um divisor de águas.

Sim, eu surrei um educando. Vivenciei todo o absurdo pedagógico, toda a ilegalidade jurídica daquele incidente, mas ao mesmo tempo vi que a limpeza das minhas mãos pedagógicas era assunto de importância secundária em confronto com o problema que eu tinha pela frente. (Makarenko, 1985, p. 29).

Esse fato e a reflexão dele decorrente permitem inferir sobre a constituição do conceito de coletividade na pedagogia makarenkeana. Demarcam um profundo questionamento das teorias pedagógicas que estudou ao longo de sua formação (Luedemann, 2002) e, ao mesmo tempo, demonstram que relativizou a violência física como algo de menor gravidade, dadas as tantas dificuldades de manter a sobrevivência. Isso, como veremos mais adiante, repetiu-se em outras ocasiões, nas quais a aplicação de castigos severos fez parte do estabelecimento da autoridade exercida por Makarenko.

Do ponto de vista prático e teórico, sua preocupação fundamental não era simplesmente formular um sistema unitário pedagógico contrapondo e superando as teorias estudadas, mas questioná-las à exaustão, a fim de balizar sua própria experiência e, assim, reconstituir uma pedagogia socialista com base na coletividade ativa de educadores e educandos.

Em fevereiro de 1921, chegou à Colônia uma carroça com 15 meninos abandonados. Makarenko (1985, p. 31) escreve:

Tivemos muito trabalho para lavá-los, vesti-los de alguma forma, curálos das sarnas. Na sua maioria eles estavam muito largados, selvagens e totalmente inadequados para a realização do sonho da educação social.

Em março daquele ano, chegaram novos educadores, o casal Ivan Ivanóvitch e Natália Markovna Ossipóv. Nesse período, o chefe do Departamento Provincial de Educação Pública fora substituído por outro dirigente soviético, que demonstrara não se importar com a Colônia Gorki. A burocracia soviética já se avolumava no poder central e o referido departamento funcionava como enfeite. Além disso, o Estado racionava alimentos, de modo que, no inverno de 1923, a Colônia não era nem de longe a imagem de um ambiente educacional. Makarenko (1985, p. 35) registra a situação:

A primeira necessidade do homem é o alimento. Por isso, a situação com as roupas não nos deprimia tanto quanto a situação com o alimento. Nossos educandos estavam constantemente famintos e isso dificultava sensivelmente o problema da sua reeducação moral. Apenas uma certa 
parte, e pequena, do seu apetite, os colonistas conseguiam satisfazer por meio de seus próprios recursos.

Os recursos complementares provinham de furtos que os jovens realizavam nas feiras da cidade. Comiam e traziam alimentos para os colegas. Makarenko não questionava, pois sabia que não poderia dar lição de moral a meninos que procuravam se alimentar naquele tempo de extrema fome.

O primeiro furto descrito por Makarenko foi o de Tarantês, caso em que se nota a ausência de respeito ao interesse coletivo por parte do educando. Ele furtou no rio algumas redes, alegando ter ganhado de amigos. Um dia levou para Makarenko um peixe, que o educador não aceitou, já que o alimento teria que ser de todos os colonistas. Os termos do diálogo relativo à oferta e à recusa foram:

- Isto é peixe para o senhor.

- Estou vendo, só que não vou aceitar.

- Por quê?

- Porque não está certo. O peixe deve ser dado a todos os colonistas.

- A troco de quê? - ruborizou Tarantês, ofendido. - A troco de quê? Eu consegui as redes, eu pesco, me molho todo no riacho, e devo dar para todos?

- Pois então fique com seu peixe. Eu não consegui nada nem me molhei no riacho.

- Mas isto é um presente para o senhor.

- Não, eu não estou de acordo, tudo isso não me agrada. Não está direito.

- Mas o que é que não está direito?

- Isto: você não comprou as redes, certo? Ganhou-as de presente?

- Foi de presente.

- Presente para quem? Pra você? Ou para todos da Colônia?

- Por que "para todos da Colônia"? Foi para mim...

- Pois eu acho que foi para mim e para todos. E as frigideiras, de quem são, suas? São de todos. E o óleo de girassol que vocês pedem à cozinheira - De quem é o óleo? E de todos. E a lenha, o fogão, os baldes? Então, o que me diz? Eu posso tirar as redes de você, e ponto final. E o pior é a falta de companheirismo. E daí que as redes são suas? Mas você faça uma para os companheiros também. Todos podem pescar, não é mesmo? (Makarenko, 1985, p. 36).

Importante compreender que a coletividade é uma práxis que se constrói nos conflitos diários da lida com os educandos e nas contradições entre a velha educação tzarista e a nova educação socialista. Nesse sentido, a militância empreendida por Makarenko não se constitui nas insurreições revolucionárias da classe operária, mas se expande a outras fronteiras do campo cultural, nesse caso, a educação.

$\mathrm{Na}$ narrativa anterior se delineia o percurso pelo qual os meninos aprenderiam formas de construir o coletivo. O educador deu o exemplo, pois, afinal, também se inseria nesse coletivo e, ao fazer compartilhar o alimento no contexto em que se encontravam, aproveitou a situação para transformá-la em comportamento assimilável. Não havia como demonstrar algo que os próprios educadores não vivessem, pois estavam, desgraçadamente, em condição de igualdade com os jovens, como se constata na seguinte passagem: 
Na nossa inenarrável pobreza havia também um lado bom, que mais tarde nunca mais tivemos. Éramos igualmente famintos e pobres também nós, os educadores. Naquele tempo, não ganhávamos quase nada, nos satisfazíamos com o mesmo condiór e andávamos envoltos em quase idênticos farrapos. No decorrer de todo inverno, eu andei de botas sem solas, com um pedaço dos trapos que serviam de meias sempre pendurado para fora. (Makarenko, 1985, p. 38).

O que havia de bom? Talvez a solidariedade que começava a se formar entre os colonistas e educadores. Todos eram semelhantes e o espírito de coletividade, nessas condições, tinha maior chance de se desenvolver, pois, para Makarenko, o universo da classe operária, tão bem conhecida por ele, apesar das severas restrições materiais, era rico em oportunidades para o desenvolvimento moral das crianças e dos jovens. Para isso, a educação deveria promover modelos culturais fortalecidos pelo coletivo e não apenas pelo indivíduo, como pregava as teorias pedagógicas dos teóricos modernos europeus, a exemplo de Rousseau, Montessori, Pestalozzi, entre outros.

Certa vez, um dos educandos furtou o dinheiro destinado ao pagamento dos professores que estava na gaveta de Makarenko. Após uma conversa com todos, tentando conscientizá-los de que estavam roubando de si mesmos, o dinheiro foi encontrado na cavalariça. Makarenko conta que até estava contente com essa circunstância e esperava que agora começassem a perceber o interesse coletivo e fossem obrigados a evitar novos furtos.

No prolongado inverno, as coisas ficaram ainda mais sérias. Um guarda florestal veio à Colônia e pediu que a floresta fosse vigiada, pois havia muitos lenhadores e ele não tinha como conter o corte ilegal das árvores. Os mesmos jovens que eram vistos de forma negativa, como seres que não tinham mais possibilidade de mudança, eram agora convocados para proteger a população e seus bens. Na concepção desse trabalho, supõe-se que Makarenko tenha percebido que seus métodos estavam sendo valorizados pela população, mas não pelo Estado, que sempre negava à Colônia ajuda e alimentos. Supõe-se também que os educandos se sentissem percebidos de outro modo; estavam agora do outro lado e não eram mais tratados como criminosos, mas como pessoas fortes e de confiança.

Assim, Makarenko idealizou em sua proposta pedagógica os destacamentos, definidos por ele como coletividade primária, da qual surgiria a coletividade geral. Um educando era nomeado líder e cada destacamento era responsável por uma atividade na Colônia. Os rapazes tinham verdadeira paixão por tudo que mencionasse a Revolução Socialista, por isso o líder de destacamento era chamado de comandante. Havia eleições para escolher os representantes dos colonos, que eram eleitos por meio do coletivo. Esses cargos eram ocupados por período de três a seis meses, o nomeado não tinha nenhum privilégio e a escolha ocorria em uma reunião denominada pelos colonistas de soviete de comandantes. Cada gorkiano conhecia o destacamento permanente a que pertencia, devendolhe disciplina. Segundo Makarenko (1985), esse sistema fazia com que os colonistas participassem não só das funções de trabalho, mas também da organização, fator essencial para que de fato a educação comunista fosse 
praticada bem aos moldes da República de Sovietes preconizada por Lênin, cuja finalidade era a autogestão da classe operária na sociedade socialista.

Outra criação de Makarenko foram as assembleias gerais, que tinham por objetivo resolver os problemas ocorridos no cotidiano da Colônia. Eles eram discutidos e resolvidos coletivamente e, após a resolução dos conflitos, não era permitido que ficassem remoendo o acontecido. Cada colono poderia falar e deveria ser ouvido por todos, não era tolerado que fizessem barulho ou se ausentassem do local da reunião. O foco das assembleias era a justiça, logo, não podiam difamar uns aos outros.

Nesse aspecto, a prática pedagógica de Makarenko afina-se com as concepções de Krupskaya. Segundo Saviani (2011, p. 31), ela defendia a ideia de que a educação escolar deveria articular as atividades de ensino com as tarefas "que possibilitassem o exercício da responsabilidade e da autonomia", de acordo com as condições e possibilidades das crianças e dos jovens. Para isso, a líder da educação socialista defendia as

[...] Organizações Infantis - Jovens Pioneiros (a partir dos 11 anos) e as Organizações Juvenis - Komsomol (União da juventude Comunista, dos 14 aos 28 anos). Seu caráter pedagógico reside no próprio poder formativo das atividades que desenvolvem - muito relacionadas com as finalidades escolares, mas com organização e funcionamento peculiares. (Saviani, 2011, p. 31).

Aos poucos os efeitos da coletividade foram aparecendo, de modo que os colonos passaram a se sentir responsáveis uns pelos outros, consolidando-se, assim, as ideias comunistas de igualdade e coletividade. De acordo com as concepções de Makarenko, era no coletivo que tudo deveria ser realizado e discutido, só dessa forma o "homem novo" seria constituído e poderia alcançar a felicidade.

Mas nem por isso as dificuldades materiais deixavam de existir. O educador pensava que a Colônia deveria priorizar a agricultura para amenizar a fome, mas o solo da Colônia era arenoso, impossibilitando a consecução desse objetivo. Segundo ele, "a pobreza levada às últimas consequências, os piolhos e os pés congelados não nos impediam de sonhar com um futuro melhor." (Makarenko, 1985, p. 56).

A vida na Colônia Gorki era organizada de forma que todos tivessem responsabilidades. Seu sistema pretendia ser autossuficiente e a sobrevivência de cada um dependia do trabalho de todos. As atividades eram divididas em dois momentos: pela manhã, a sineta soava para o trabalho agrícola e de manutenção dos prédios da Colônia; à tarde, os alunos assistiam às aulas, complementadas à noite - durante o frio inverno - nos dormitórios com a leitura de livros de Gorki nas rodas de leitura coletiva.

O trabalho dos educadores dividia-se em: a) plantões principais, das cinco da manhã até a noite, tendo o plantonista a incumbência de supervisionar as tarefas diárias; b) plantões de trabalho, em que os educadores orientavam os alunos, geralmente no lugar em que os colonistas faziam serviços, como na carpintaria e na ferraria; e, finalmente, c) plantões noturnos, que acabaram se tornando uma informalidade, já que todos se reuniam nos quartos para 
conversar e ler. As pedagogias socialistas que buscaram os fundamentos na teoria marxiana oscilaram, historicamente, em como aplicar o trabalho como princípio educativo ou realizar a formação omnilateral. No caso presente, concordamos com Manacorda (2000), em sua afirmação de que o trabalho muitas vezes fora utilizado como educação moral ou, mais propriamente, como função didática de aproximação da experiência e da aprendizagem. Ademais, em uma perspectiva mais realista, a finalidade do trabalho era manter a sobrevivência dos colonistas e educadores.

A Colônia foi-se desenvolvendo e novos jovens chegaram. Todavia, esses educandos não estavam dispostos a obedecer as normas, o que, segundo Makarenko, causava forte abalo no frágil coletivo. Contudo, nenhum tipo de desrespeito para com os educadores acontecia, uma vez que os antigos colonistas faziam questão de contar aos novos como o início fora difícil e o quanto de respeito deviam aos docentes (Makarenko, 1985).

Os garotos recém-chegados, na convivência com os veteranos, desentendiam-se constantemente por bobagens, exigindo dos educadores o recomeço das ações pedagógicas. Parecia que os esforços retirados do mais íntimo de cada educador reiniciavam a cada vez que chegavam novos educandos, com seus costumes da vida pregressa.

E por que os rapazes não fugiam da Colônia? A vida na rua, na pobreza da população russa pós-Revolução, não oferecia nada que fosse mais desejável, já que na cidade as pessoas passavam mais fome do que os educandos. Além de menores abandonados, eram recebidos meninos em conflito familiar que o Estado designava como "dificilmente reeducáveis" (Makarenko, 1985, p. 74). Um dia, um dos educandos entrou no quarto de Makarenko e, agoniado, falou que os rapazes estavam se esfaqueando no dormitório. O educador saiu correndo e encontrou a cena de dois grupos brigando. Ele permaneceu na porta, até que todos notassem sua presença, pois nunca separava brigas ou gritava mais alto do que os briguentos. Diante disso, esconderam as navalhas e se calaram. Makarenko (1985, p. 76) narra:

Então, súbito, expludo eu mesmo, assolado por uma erupção de raiva verdadeira e com plena e consciente convicção de que assim tem de ser: - As facas na mesa! E rápido, com os diabos!...

As facas são colocadas sobre a mesa: navalhas finlandesas, facas de cozinha especialmente apanhadas para a represália, canivetes e lâminas fabricadas na nossa própria oficina.

No dormitório, Makarenko aguardou todos dormirem e saiu do quarto. Na manhã seguinte, nem os rapazes nem o educador falaram sobre o assunto. Percebendo que um dos jovens, Tchóbot, incitava as brigas, Makarenko (1985, p. 77) tomou uma decisão:

- Você terá de deixar a Colônia.

- E para onde irei?

- Aconselho que vá para um lugar onde é permitido esfaquear os outros.

Hoje só porque um companheiro não lhe cedeu o lugar à mesa, você o espetou com uma faca. Então, procure um lugar assim, onde as discussões se resolvem a facadas. 
Pela manhã, ele se despediu e disse a Makarenko que era grato por tudo que lhe havia ensinado. O educador lhe asseverou que, se as coisas ficassem difíceis, ele poderia retornar, mas não antes de duas semanas. Em um mês ele retornou.

- Então eu vim, como o senhor falou.

- Não encontrou aquele lugar?

Ele sorriu.

- Por que "não encontrou"? Existem lugares assim...

- Eu vou ficar na Colônia, não pego mais numa faca.

No dormitório, os colonistas o saudaram carinhosamente:

- Então o senhor sempre o perdoou! Nós não dissemos? (Makarenko,

1985, p. 77).

Makarenko sempre dava nova oportunidade a cada educando que desejasse permanecer na Colônia sob sua disciplina. Observa-se que os gorkianos, apesar do rigor das ações do educador, respeitavam-no e acreditavam em seu perdão como nova chance para transformar seus comportamentos. Mas, além disso, o que importa apreender é que o conceito de coletivo para a pedagogia em análise é pressuposto fundamental para a formação da consciência social baseada na solidariedade e responsabilidade de cada um com o todo, sem a qual a vida se desagrega e volta às condições passadas de delinquência e de uma sociedade fundada, sobretudo, no indivíduo e não no corpo social dos sovietes.

Mais jovens chegaram à Colônia Gorki. Desta vez eram judeus e, para complicar a situação, chegaram também outros garotos, antissemitas. Os primeiros eram espancados e ameaçados, a começar por Ostromúkhov, cuja comida estragavam, além de insultá-lo. Outros jovens judeus passaram a ser perseguidos, mas, por medo, não se queixavam a Makarenko. Ossádchi, antigo colonista, que gostava de exercer poder sobre os outros, especialmente, nessa situação de fragilidade dos judeus, tornou-se o principal algoz desses jovens. Ao perceber tal ação, o educador pediu aos que tinham bom comportamento que conversassem com os antissemitas, mas não houve concordância. Makarenko se viu sem solução e convocou Ossádchi para seu quarto. O rapaz demonstrou não sentir nenhum tipo de arrependimento e pediu que Makarenko o expulsasse. Ele negou, pois Ossádchi seria considerado herói entre os educandos.

Durante uma das refeições, Ossádchi estava obrigando Schnaider a servir sopa, quando este, sem querer, colocou o dedo no alimento. Ossádchi deu um bofetão em Schnaider. De forma inesperada, Ostromúkhov saltou em cima do antissemita para defender seu companheiro e todos os outros judeus, que não conseguiam viver tranquilamente. Foram obrigados a ir falar com Makarenko, que precisava resolver o problema ou ficaria impossível conviver na Colônia com os novos jovens. Segundo o educador:

Gelava-me e me deprimia a indiferença pelos espancamentos no refeitório manifestada por todos os colonistas, até os iguais a Zadórov. Senti de repente que agora estava tão isolado e solitário como nos primeiros dias da Colônia. Mas nos primeiros dias não esperava apoio e simpatia de parte alguma, era uma solidão natural e prevista, porém agora eu já tivera 
tempo de ficar mal acostumado e contar com a cooperação permanente dos colonistas. (Makarenko, 1985, p. 123).

Ao chegar ao quarto de Makarenko, Ossádchi não se sentiu nem um pouco ameaçado pelo chamado do educador, o que provavelmente ocasionou sua perda de controle. Makarenko jogou um ábaco em direção à cabeça do jovem, que, no entanto, não foi atingido, pois o instrumento bateu na parede. Em seguida, jogou a cadeira e o educando caiu no chão ao escorregar no casaco. A sentença a Ossádchi foi permanecer quatro dias na sapataria a pão e água.

No primeiro dia da prisão, ele me chamou à sapataria e pediu:

- Não vou fazer mais, perdoe-me.

- Sobre o perdão ainda vamos conversar, depois que você cumprir o seu tempo.

Após os quatro dias de prisão ele já não pedia perdão, mas declarava taciturnamente:

- Vou embora da Colônia.

- Pois vá.

- Dê-me um documento.

- Nada de documento.

- Adeus.

- Boa viagem. (Makarenko, 1985, p. 125).

Contraditoriamente, observa-se que Makarenko recorre à violência física como forma de extinguir a violência. A denominação sapataria faz referência às formas mais cruéis de aprisionamento, em que o confinado não tinha direito nem mesmo à luz do sol. O educador não aliviou a sentença de Ossádchi, provavelmente porque viu que o garoto não demonstrava arrependimento, apenas queria fugir da dura pena. Ainda que possamos considerar a gravidade da ação do jovem educando, que exercia um preconceito racial característico tanto da Europa Ocidental quanto do leste Europeu, que afetava a integridade humana, é questionável que uma violência venha corrigir outra, imaginando que possa se constituir em um processo educativo.

Na lida diária, os rapazes aprendiam a conviver no coletivo, riam, trabalhavam, mas ele se questionava se ia descobrir realmente como tornar esses meninos felizes, se seria preciso começar novamente. Questionava-se sobre sua impotência:

Há quantos milênios ela existe! Que nomes, que ideias brilhantes: Pestalozzi, Rousseau, Natorp, Blonsky! Quantos livros, quantos papéis, quanta glória! E, ao mesmo tempo, um vácuo, não existe nada, é impossível haver-se com um só desordeiro, não há nem método, nem instrumental, nem lógica, simplesmente não existe nada! Tudo uma enorme charlatanice. (Makarenko, 1985, p. 127).

Sentia-se impotente por não saber como poderia resolver os problemas que insistiam em aparecer sob novas formas no cotidiano da Colônia. Chegou a pensar que nada fazia efeito na reeducação dos jovens, entretanto, sua firme decisão e vontade para alterar esse quadro não o abandonavam. 
No início da Colônia Gorki, havia apenas três meninas, que tinham sido enviadas para a Colônia por furto: Ólia Vóronova, Marússia Liêvtchenko e Raissa Sókolova, sendo as duas últimas consideradas levianas pelo educador, pois bebiam e jogavam cartas com os garotos, bem como se portavam com independência em relação aos rapazes.

Vale ressaltar que a posição do homem e do educador Makarenko traz a marca de uma visão social fundada em valores machistas, segundos os quais a liberdade sexual feminina é vista sob o ângulo da moralização. No entanto, o rigor histórico recomenda cautela no julgamento, afinal, as questões de gênero, mesmo nas tendências e posições políticas mais progressistas, só foram pautadas a partir dos anos 1950. Portanto, a questão classista ocupava quase que exclusivamente o foco das experiências socialistas, de sorte que a exclusão da discussão acerca do gênero estava sob o prisma dos valores sociais da época.

No inverno de 1922, já havia seis meninas, entre as quais a mais instruída era Raissa, que, não obstante, continuava a cometer seus pequenos delitos. Em março do mesmo ano, chegou a Makarenko, por meio de um educando, a notícia de que Raissa estaria grávida.

Eu gelei. Estávamos numa situação difícil: imaginem só, numa Colônia infantil, uma educanda engravidou. Eu sentia, em torno da nossa Colônia, na cidade, no Departamento de Educação, a presença de grande número daqueles virtuosos hipócritas que não deixariam de aproveitar a oportunidade para levantar uma enorme gritaria: há depravação sexual na Colônia, na Colônia os meninos coabitam com as meninas. Assustava-me o próprio estado de coisas na Colônia tanto quanto a situação complicada de Raissa como educanda. (Makarenko, 1985, p. 136).

Na ausência de confirmação da gravidez, Makarenko insistiu em perguntar à jovem se estava grávida, alegando que ele daria todo apoio e que ela iria trabalhar e criar seu filho. Ela, no entanto, negou insistentemente até que um dos jovens procurou Makarenko e comunicou-lhe que havia uma criança morta na Colônia. O educador pediu ao jovem que fosse à milícia contar o ocorrido e disse que iria mais tarde. O fato era que Raissa dera à luz durante a noite e, após o nascimento, estrangulara a criança com um lençol e escondera o cadáver numa cesta, pensando levá-lo para o matagal, onde as raposas o devorariam, ficando, assim, tudo resolvido.

Ao chegar, Makarenko manteve o seguinte diálogo com Raissa:

Pra que fizeste isso?

Raissa levantou a cabeça, fitou-me com um olhar obtuso de animal e arrumou o avental sobre os joelhos.

- Fiz, e é só.

- Por que não me ouviste?

Ela começou a chorar baixinho.

- Eu mesma não sei. (Makarenko, 1985, p. 138).

Em três meses Raissa foi julgada pelo Estado. Todos os educadores foram convocados, e o juiz perguntou a Makarenko: "O senhor pode aceitá-la de volta na Colônia?". Ele respondeu: "Naturalmente." (Makarenko, 1985, p. 141). 
Ela foi condenada a oito anos e imediatamente foi entregue aos cuidados de Makarenko. A convivência com as ex-companheiras após sua volta foi muito difícil, uma vez que ninguém a aceitava. Assim, o educador, procurando amenizar os ânimos na Colônia e, ao mesmo tempo, uma saída digna para a moça, conseguiu-lhe emprego em uma malharia. Em 1928, Makarenko a encontrou trabalhando atrás de um balcão. Ela contou que tinha marido e dois filhos e agradeceu seu professor, dizendo: "Obrigada, porque naquele tempo o senhor não me afogou. Eu, assim que entrei para a malharia, desde então atirei fora o meu passado." (Makarenko, 1985, p. 142).

Makarenko rompeu com muitos procedimentos e dogmas de sua época, instituindo, entre diversas outras práticas, a coeducação e o trabalho remunerado dos colonistas, porque acreditava ser essa uma forma eficaz de torná-los cidadãos. O Departamento de Instrução Pública, incomodado com suas metodologias, iniciou intensa perseguição. Falaram ostensivamente: "Nós vamos liquidar com essa sua experiência policialesca. É preciso construir uma educação socialista, não uma caserna" (Makarenko, 1985, p. 152).

O educador tinha posições firmes e contrárias ao que o Departamento preconizava. Segundo ele:

Eu me permiti externar a minha profunda convicção de que, enquanto não estiverem criados o coletivo e os órgãos do coletivo, enquanto não existirem tradições e não forem criados hábitos elementares de trabalho e de vida, o educador tem o direito, e não deve renunciar a ele, de usar a força e de obrigar. Afirmei também que não era possível basear toda a instrução sobre o interesse, que a educação do senso de responsabilidade e do dever muitas vezes entra em conflito com o interesse da criança, em especial da forma como esta entende. Eu exigia a educação de um ser humano resistente e forte [...]. (Makarenko, 1985, p. 152).

Makarenko receava pelo fim da Colônia, mas não vivia angustiado, as ocupações não lhe permitiam isso. Um dos inspetores, Shárin, era renitente perseguidor de Makarenko, especialmente desde o dia em que o educador não conseguira reprimir o riso diante de algo que o inspetor dissera. Certo dia, um novo educando foi admitido na Colônia a pedido da Seção Especial. Shárin ficou extremamente incomodado por terem passado por sobre sua autoridade e questionou Makarenko:

- O senhor admitiu Ievguêniev?

- Admiti.

- Que direito tinha o senhor de admitir um educando sem o nosso consentimento?

Expressou imediatamente o seu mandato que mandasse embora o garoto.

- Despache imediatamente o Ievguêniev de volta.

- Só com uma ordem escrita do senhor.

- Para o senhor deve bastar minha ordem oral.

- Dê-me uma ordem escrita.

- Eu sou seu superior e posso detê-lo por sete dias pelo não cumprimento da minha ordem verbal. (Makarenko, 1985, p. 155).

Makarenko prosseguiu ignorando as ordens dadas. Dessa forma, Shárin ordenou sua prisão. "Milícia? Mandem imediatamente um miliciano 
para prender o diretor da Colônia Gorki, que eu detive por sete dias... Shárin." (Makarenko, 1985, p. 155). Nesse caso, Makarenko pediu auxílio ao presidente do Comitê da Província e foi logo liberado.

Ao regressar à Colônia, o educador foi surpreendido com os educandos apavorados. A Colônia havia sido revirada pelos burocratas da educação.

- Sabe, tudo aconteceu tão depressa, como se despencasse de não sei onde. Eles chegaram de automóvel, poucos sequer repararam, estavam todos trabalhando. Foram ao seu gabinete, fizeram não sei o que lá, um dos nossos foi espiar, viu que remexiam nas suas gavetas. O que é isso? Os rapazes correram para sua porta, mas aí eles saíram de lá. (Makarenko, 1985, p. 157).

A burocracia estatal soviética não demorou a criar todo tipo de barreira e iniciar formas de inibir a experiência educacional. Havia o temor de que um processo orgânico de contestação da realidade de vida e dos ideais do socialismo viesse de fato se concretizar naqueles julgados delinquentes e sem futuro. Por parecer uma subversão ao sistema, isso havia de ser coibido.

\section{Considerações finais}

Muito se comentou e ainda se comenta acerca dos métodos contraditórios e mesmo antagônicos de Makarenko, segundo o qual podemos ser exigentes com as crianças e os jovens, ignorá-los e até ser indiferentes, mas, quando fazemos com sabedoria e exatidão nosso trabalho, elas sempre estarão ao nosso lado e não nos desapontarão. No entanto, se formos gentis e amáveis e não demonstrarmos sucesso no que fazemos, eles nos desprezarão (Makarenko, 1985).

De acordo com a compreensão deste trabalho, Makarenko é um intelectual orgânico na acepção gramsciana (2000), porque conseguiu captar o espírito das transformações sociais, políticas e econômicas da então URSS, na medida em que propôs um processo educativo envolvendo professores, funcionários e estudantes para vivenciar a experiência da organização social e educativa da Colônia Gorki de modo coletivo, em face de um contexto adverso para a sobrevivência. Desse modo, procurou construir a autonomia e consciência daquele grupo de jovens que vivia em situação de delinquência, fazendo com que refletisse sobre suas condições de classe social.

Por outro lado, ao revisitar a obra de Makarenko, também não se pode ignorar a recorrência de práticas de violência física e moral que perpassaram sua experiência educacional socialista. O educador ucraniano, em sua ânsia de formar o coletivo para a nova sociedade socialista, não se questionou sobre sua opinião pré-formada a respeito dos próprios jovens que chegaram à Colônia, considerando-os vagabundos e delinquentes. Além disso, é preciso recordar o modo misógino com que se referiu ao comportamento sexual das meninas que chegaram à Colônia de Gorki. Em se considerando o emprego da força física e de penosos castigos na educação dos jovens, o educador não se distanciou de práticas educativas opressoras que subjugavam os 
estudantes, que, hierarquicamente, estavam em desvantagem na estrutura educacional.

A leitura de Poema pedagógico nos faz perceber um homem que expõe suas fraquezas e seus sucessos; revela sua natureza humana sem esconderijos, sem máscara de herói da educação; expõe-nos quão penoso é dedicar-se a ser mestre, em um contexto de transformação do futuro dos estudantes e da nova URSS. Makarenko demonstrou ser um sujeito obstinado e, ainda que de modo contraditório e paradoxal, o educador investiu em cultura, em formação de laços afetivos, em formas de autoorganização, enfim, em criação de um coletivo que envolvesse professores e educandos de uma forma que não fosse apenas mais uma experiência a ser vivida, mas se transformasse em uma nova maneira de encarar a difícil tarefa de viver em um contexto de profunda transformação política.

Para Anton Makarenko, era fundamental educar as pessoas para o momento histórico vivido pela sociedade soviética, fazendo do processo educacional uma experiência pedagógica consciente das condições dadas, mas sem o desespero diante dos obstáculos apresentados pelas circunstâncias.

A partir da narrativa de Poema pedagógico, é possível defender a atualidade dessa obra que aposta na reeducação de jovens que foram jogados à própria sorte e, consequentemente, impelidos para a criminalidade. Ainda que imatura, a experiência educacional comunista rompe com uma das mais poderosas lógicas da educação burguesa - a centralidade da educação no indivíduo -, a fim de fortalecer a personalidade do sujeito por meio do coletivo e, em nome dele como fim e como meio, buscar construir a educação socialista.

O período de 20 anos de experiência, contudo, não foi suficiente para tal consolidação, mas foi o bastante para provocar nos educadores atuais de toda nacionalidade a reflexão de que outras bases pedagógicas podem ser formuladas e vividas com ousadia e atrevimento, a fim de evidenciar que aprofundar a coerência entre uma concepção política e pedagógica ainda é o melhor fundamento para construir a transformação social, pois se elabora o passado para que o presente não repita os limites e equívocos a respeito da formação humana.

\section{Referências bibliográficas}

CAPRILES, R. Makarenko: o nascimento da pedagogia socialista. São Paulo: Scipione, 1989.

FACHIN, O. Fundamentos de metodologia. 5. ed. São Paulo: Saraiva, 2006.

GRAMSCI, A. Cadernos do cárcere. Tradução de Carlos Nelson Coutinho. Rio de Janeiro: Civilização Brasileira, 2000. v. 2. 
KRUPSKAYA, N. La unión de la juventud. 1917. Disponível em: <http:// marxists.org/espanol/krupskaya/1917/mayo27.htm>. Acesso em: 15 maio 2012.

LÊNIN, V. I. Teses de abril. São Paulo: Mandacaru, 1990.

LUEDEMANN, C. da S. Anton Makarenko: vida e obra: a pedagogia na revolução. São Paulo: Expressão Popular, 2002.

LUNATCHARSKI, A. V. Decreto sobre la a educación popular. 1917. Disponível em: http://marxists.org/espanol/lunacha/obras/1917-11-11. htm. Acesso em: 15 maio 2012.

MAKAREnKO, A. S. Poema pedagógico. Tradução de Tatiana Belinky. São Paulo: Brasiliense, 1985.

MANACORDA, M. A. Marx e a pedagogia moderna. Tradução de Newton Ramos de Oliveira. 3. ed. São Paulo: Cortez, 2000.

SAVIANI, N. Concepção socialista de educação: a contribuição de Nadedja Krupskaya. Revista HISTEDBR On-line, Campinas, v. 1, n. 41 esp., p. 28-37, abr. 2011.

Recebido em 3 de março de 2015.

Solicitação de correções em 8 de setembro de 2015. Aprovado em 25 de abril de 2016. 